3) Finally, the teacher has to prepare the questions to check whether students have understood the text in more details.

As a result, students will be better able to reproduce the content of the texts in their own words. All of the stages above will help students to understand the context of the subject matter texts and prepare them for further content learning. It is considered appropriate to accompany the texts with illustrations so that students can visualize what they are reading.

To sum up, CLIL lessons have a lot of advantages compared to traditional education at universities. Authentic texts which are used in this approach are effective means of studying both the subject and the language however they might be sophisticated for the low proficient students. Nevertheless, with the teacher`s guidance and support, it will become an effective source of learning.

\title{
References:
}

1. Larsen-Freeman, D., \& Anderson, M. (2011). Techniques and principles in language teaching. Oxford: Oxford University Press.

2. Marsh, D. (2012). Content and Language Integrated Learning (CLIL). A Development Trajectory. Córdoba: University of Cyrdoba.

3. Nosonovich, E. V. (2000). Metodicheskaya autentichnost' v obuchenii inostrannym yazykam [Methodological authenticity in teaching foreign languages]. Foreign languages at school, no. 1, pp. 11-16.

\section{THE DIVERSIFICATION OF HIGHER EDUCATION AS A GLOBAL TREND OF MODERNITY}

\section{Alla Ziakun ${ }^{1}$ \\ DOI: https://doi.org/10.30525/978-9934-588-39-6-5}

The education system, like the culture of its people, is a unique phenomenon because it is deeply linked to the spiritual and material aspects of the past and present. Therefore, in every country, education and its organization have its own peculiarities. In today's world of globalization, priorities and demands for learning and upbringing are changing. Therefore, higher education reform is inevitable. However, on the one hand, it is necessary to take into account the priorities of preserving the cultural diversity of national education systems, and on the other hand, to solve the problems of improving international cooperation, mobility, employment of students in the

${ }^{1}$ Sumy State University, Ukraine 
European or international arena, international competitiveness of higher education institutions.

Today, the structure of the world higher education is extremely diverse, but it is dominated by two trends: a unitary or unified system and a binary or dual education system. In the unitary (unified) system, higher education is provided by universities or institutions corresponding to them, offering both general academic degrees and vocationally oriented programs of varying lengths and levels. The peculiarity of this higher education system is that it comprises only universities, and the proportion of other higher education institutions is a small percentage. An examples of such education are Italy, Spain, Austria, Finland, Sweden. Under the binary (dual) system, education is provided by the traditional university sector, based on the concept of Humboldt University, and by a distinct non-university higher education sector, with a clearly defined structure. Such an education system is common to most countries, including Belgium, the United Kingdom, Greece, Denmark, Ireland, the Netherlands, Norway, Germany, France, Switzerland [1].

Today, the trend of improving and expanding «short and professional» higher education is quite effective in current educational trends. It is intensive study at a higher education institution or a certain department of a university for a short period of time, up to three years. An example is the recently established in university institutes in France, where a thorough education is obtained for a limited time and under the conditions of good organization of the educational process.

Current trends in the transition to a unified university system and the development of the higher education sector of the non-university level have formed a new understanding of the concept of «university» - an institution with intensive cooperation, coherence between teaching, learning and success in it, where much attention is paid to the individual. This trend is noticeable in the universities of countries that are actively immersed in the process of creating an information society. Until recently, poorly structured higher education systems performed a limited number of tasks to preserve and strengthen the state structures of the country, to conduct scientific and technological research with the simultaneous preparation of scientists, as well as to provide economics with highly qualified specialists. In most of the countries listed above, higher education institutions performed through the use of mono-disciplinary training, where higher education was general and professional training was transferred to jobs (a classic example is Japan) [2, p. 109].

Instead, the main tasks of organizing higher education institutions that have vocationally-oriented programs of study in parallel with the university sector are the same for most countries. It is to offer vocationally oriented and cost-effective types of education to meet the needs of the labor market; to 
meet the needs of an increasing number of entrants without significantly increasing government spending on higher education; propose programs that will use applied research; renewal and improvement of already existing vocationally oriented education. Another area of global education trends is the parallel diversification of degrees and qualifications issued by different educational institutions. And here, too, there are two traditional structural trends. The first is the Continental European Degree structure with a long academic degree and the second is an Anglo-American University Degree with a shorter first-cycle degree and a variety of post-bachelor degree programs, partly based on a modular system. In some countries, the types of shorter cycle degrees are introduced into the national degree structure (Denmark, Finland, Italy and Portugal). In other countries, such a system is implemented in conjunction with the traditional stepped structure (Germany and the Netherlands) [1, p. 85].

Continuous diversification of qualifications is also taking place in the nonuniversity sector. In order to meet the requirements of the labor market in certain professional fields, a large number of new bachelor degree programs have been introduced, and a number of postgraduate courses have been developed. These may be completed with a national or dual specialization degree. Non-university educational institutions that do not qualify for master's programs may, at their request, cooperate with foreign institutions that have such a right. Therefore, in this way, these educational institutions have the opportunity to offer students international master's programs. At the same time, higher education institutions in the non-university sector do not offer doctoral degrees, but this does not mean that applicants for doctoral programs from non-university sectors cannot study for them. In some countries, such candidates are able to access the doctoral $(\mathrm{PhD})$ program at the university immediately (Norway and the Netherlands) or through preparatory courses (Austria and Germany) [2, p. 110-111].

Thus, increasing diversification is generally considered a positive phenomenon for higher education systems, both within the country and in the international context. However, it also has problems - a lack of transparency in the qualifications structures of individual countries; difficulties in the mutual recognition of qualifications due to the large number of different levels and variations in the content of qualifications. Therefore, addressing these challenges drives the global scientific and pedagogical community to seek new tools for the interaction of national education systems in the global higher education qualification. 


\section{References:}

1. Ilchenko, A. (2014). Vishha osvita i Bolonskij proczes: Navchalno-metodichnij posibnik [Higher education and the Bologna process: Textbook]. Poltava: RVV PDAA, 316 p. (in Ukrainian)

2. Artyomov, I. (2015). Innovacziyi v osviti i nauczi okremikh krayin Yevropi, Aziyi ta Ameriki [Innovations in education and science of individual countries of Europe, Asia and America]. Uzhgorod, 205 p. (in Ukrainian)

\section{ELECTRONIC CONTENT OF DISTANCE LEARNING IN HIGHER EDUCATION}

\section{Oksana Ivanova ${ }^{1}$ \\ Olena Krekoten $^{2}$}

DOI: https://doi.org/10.30525/978-9934-588-39-6-6

With the rapid technological development of society, there is a constant need to solve complex problems quickly and effectively. Therefore, using high-tech teaching methods, such as electronic educational resources, is of acute importance nowadays.

Knowledge goes out of data every 3-5 years, technological knowledge becomes obsolete every 2-3 years. With a little more time it will be 1, 5-2 years. As for content knowledge of graduates, it doubles every 3-4 years. If educational technologies are not changed, the quality of specialists' training will lag far behind the level needed in the labour market [1]. Society has a requirement in personality, able to self-education. Nowadays, the words «study» and "work» have become synonyms, united in the distance learning mode.

Distance learning is a set of technologies providing students with main teaching support materials, the interactive cooperation of students with their teacher in the training process, giving students the opportunity to work with educational materials both individually and during the training process. Different methods of providing educational information can be used in distance learning [1].

In recent years, the number of people studying on non-traditional technologies has grown rapidly. The long-term aim of distance learning development all over the world is to give opportunity to every student living anywhere to take a learning course of any educational establishment

\footnotetext{
${ }^{1}$ Sumy National Agrarian University, Ukraine

${ }^{2}$ Sumy National Agrarian University, Ukraine
} 